\title{
Family leadership and environmental sustainability: a case of the single fathers in Russia
}

\author{
Olga Bezrukova $^{{ }^{*}}$, Valentina Samoylova ${ }^{1}$, Maria Yashina $^{1}$ \\ ${ }^{1}$ Department of Sociology, Saint-Petersburg State University, Universitetskaya Emb. 7-9, 199034 \\ Saint-Petersburg, Russian Federation
}

\begin{abstract}
Nowadays, the traditional perception of the family is changing. However, understanding children preferences and shaping their views of the world still remain the key prerequisites for the environmental sustainability. The purpose of the article is to analyze models of single fatherhood, to study the motivation and structure of factors that determine the involved fatherhood making, the specifics of mother's and parent family's influence on the paternal practices implementation. Our research testifies to the fact that single fathers tend to become family leaders and undertake responsibility related to childcare in the context of transforming marital and family relations as well as facing global environmental issues. The results of the study show that single fatherhood is usually a forced situation caused by death or severe illness of the mother, her deviant behavior and leaving the family, deprivation of parental rights, divorce consequences, long-term separation of spouses, use of modern reproductive technologies of surrogacy. It is concluded that the scenarios of the single fatherhood becoming - planned or casual - are associated with the cause of the child appearance in the family. The significant differences are found in the social and cultural capital of the single fathers which might have different impacts on the level of environmental education they can pass on to their children.
\end{abstract}

\section{Introduction}

The number of the single fathers grow throughout the world, and the same trend is observed in Russia. According to the 1989 Population Census, the share of the paternal monoparenthood was only $1.0 \%$ of total number of the families [1].The results of the 2010 All-Russian Population Census demonstrated increase of the paternal families share in total number of the family cells with minor children under 18 up to $3.7 \%$ [2] and the 2015 Microcensus gave us 3.2\% [3]. These phenomenon is caused by the recent changes in our society such as globalization, precarization, but also global climate change and all its adverse effects.

The research interest shown by the Russian authors in the problems of the paternal families can be observed in the analysis of the causes and typology of the male

*Corresponding author: o.bezrukova@spbu.ru 
monoparenthood, characteristics of a social portrait of the single father with children, experienced difficulties, educational practices [4-10], contradictory generation of "caring" masculinity and involved fatherhood $[11,12]$ as well as in the study of protection of rights, technologies, and measures enabling to support the single fathers as new clients of the social services $[6,8,13]$. Deficient researches and poor studies of the single fathers as a social group give rise to its polar assessments: from positive heroic images of forced single fatherhood due to severe illness, death, or deviance of the mother [14] to negative ones relating to the fathers estranged or underperforming their parental responsibilities $[8,15]$.

A separate category of the Russian publications is devoted to description of practices of working with fathers in various governmental and non-governmental organizations. In the presented studies, the main factors of the increasing paternal monoparenthood are family instability and transformation of family values; decrease in parental role asymmetry due to breaking traditional gender order; fatherhood development as a parental substitute, appearance of a "new" masculinity and alternative models of paternal behavior, growth of paternal movements, prevalence of labor precarization, educational and professional mobility $[4,12]$. The foreign researchers state that although, as before, the majority of single parents are mothers, the number of single fathers who are the main guardians of their children is gradually increasing [16]. Some of the few studies devoted to such families review the content and specifics of the parental functions of the fathers compared to the mothers. The analysis of four categories identified for child care activities (routine care, games, management, and training) shows that the single fathers spend far less time for child care than the single mothers do (average time spent by the fathers is 54 minutes and the same by the mothers is 1 hour 39 minutes) in all categories of the child care activities except for the games [16]. These data confirm the earlier studies $[17,18]$ and fit into a gender paradigm according to which women and men behave in accordance with the social expectations and standards regarding their gender. As a result, the gender contrasts that are considered to be natural and justified ones are acknowledged, and it is reasonably to expect in the future that single fathers will be less involved in most child care activities than the mothers creating certain risks to the well-being of their children. At the same time, it is noted that the structural characteristics of the immediate environment affect the balance of the parental functions: the gender differences in the total time of child care are mitigated if female family members are near the father and child or, on the contrary, time shortage of communication with the child increases if the family includes other male family members [16].

In any case, the father bears the primary responsibility for the children upbringing and his participation and involvement become necessary conditions for transfer of social capital resources to the child. According to the study of [19], the teenagers from the families with the single fathers report of the higher level of participation of their fathers than the teenagers from the families with married birth-fathers or stepfathers; however, the levels of involvement, supervision, monitoring, and closeness with the children of the single guardian fathers is lower than the same of the guardian mothers. The families with the single fathers which do not differ from the families with both parents in terms of the fathers' education are less vulnerable in terms of socio-economic resources than the families with the single mothers [19]. The economical benefits allow children from these families to receive more resources for intellectual development that is confirmed by the higher test results [17]. At the same time, in terms of financial and material resources, such families are still inferior to twoparent families [20]. More educated fathers are often more bound with their children, and the presence of the uneducated single father limits the children ability to generate human capital [21] and reduces possibility of their successful social adaptation during the transition to adulthood.

The studies of the family social environment show that the single guardian fathers less often use reputing parenting practices and more often adhere to the strategies of 
permissiveness and non-intervention. The facts suggests that the teenagers from such families have a higher level of isolation than the children from the two-parent families [20]. The above studies allow to conclude that the single fathers can have poor resources including social support to fully cope with the parental functions and ensure the well-being of their children, and the most noticeable shortage concerns their educational competence.

\section{Methodology and methods}

The research methodology includes consideration of the fatherhood as a social institution, a system of rights, obligations, social expectations, environmental and natural concerns, as well as the requirements applied to the man as the parent and rooted in the regulatory system of culture and in the family structure (fatherhood); as an individual and reflective social practice (fathering), multipurpose and multidirectional event, complex phenomenon consisting of many structural components and exposed to various influencing factors $[11,22$ 25]. In addition, we examined the fatherhood in terms of social changes in manliness, generation of non-dominant masculinities, construction of "caring" masculinity by the men and society, "new culture" of fatherhood [26, 27]. The responsible fatherhood is an integral part of the concept of "responsible parenthood" which is built based on the adoption of a new masculinity model and includes such indicators as emotional closeness with the children, involvement in direct care, communication and games with the child, child minding, responsibility for their physical and personal development [23, 28].

The purpose of the article is to analyze models of the single fatherhood, to study the motivation and structure of factors that determine the involved fatherhood making, the specifics of mother's and parent family's influence on the paternal practices implementation. The main tasks of the study include examination of the typical scenarios of the man becoming the single father, their social problems and practices, development of recommendations regarding single fathers' support.

Empirically, the article is based on the data of the study carried out in 2019 in SaintPetersburg. The targeted sample group included 17 interviewees as the single fathers. They were from 37 to 50 years old. They had experience of living with the children aged 9 months and older. The children age varied from 2 to 15 years. 9 persons had higher education and 8 persons had vocational secondary education. Among them, 7 fathers were widowers, 7 fathers were divorced with the child living with the father, 1 father was married, 1 father was in the unregistered marriage, and 1 case was with the mother was deprived of the parental rights. 11 persons had one child, 5 fathers had two children, and 1 father had three children. The financial situation was assessed as good by 6 persons and as satisfactory by 11 persons. An in-depth interview was used as the study method. The interview duration ranges from 1 to 3 hours.

\section{Results/findings and discussion}

The common feature of the fathers in this target group is the fact that they bring up their children alone without the wife but still to give their offspring the best knowlede and the education of the surrounding world [29]. The reason for this situation is the basis for their classification and determines, to a great extent, the patterns of their paternal behavior. Based on the life circumstances, the fathers become single parents as a result of the wife's death or family leaving by the child mother including the divorce. The family leaving by the mother can be caused by her asocial behavior entailing sometimes the deprivation of her parental rights. The mother can have no asocial behavior, but due to difficult relations between the spouses, she voluntarily refuses parenthood and agrees with the court decision that the child 
will live with the father after the divorce. In addition to the formal grounds for classification, the accepted approach to fatherhood understanding as a part of the personality sphere of the man can be taken into account. For men of this group, the main characteristics are implementation of the "responsible fatherhood", active involvement in the caring and raising the children not so much due to the circumstances but as a need to fulfill oneself as a father.

The initial scenarios of the single fatherhood becoming connected with the circumstances of the child appearance in the family - planned or casual - can differ. Without regard to this circumstances, the significant differences are found in the social and cultural capital of the single fathers. The fathers with the expanded capital are usually involved into active emotional and educational relations with the child. The children participate in leisure activities of their fathers, adopt their experience in everyday communication; the families actively travel together, visit the cultural and leisure events. The fathers exercise the initiative in the event of any psychological difficulties of the child, visit medical and other professionals. They build trust-based relations with the child without any violence, establish positive interconnections with educational and health institutions that the child attends. They position themselves as independent, accomplished, and parents; they do not resort to financial assistance from the governmental structures.

In case of the poor social and cultural capital of the father, there is a shortage of parentchild relations, low level of trust and mutual interest; the child grows to a large extent as an autonomous subject that does not demonstrate the need (however, this does not mean that the child has no need) in affection and emotional closeness with the father. The fathers prove themselves as passive participants in relations with the children, they mainly focus on the financial component of support. The father fulfills himself primarily as a breadwinner or provider of means of substance that are often quite modest. The child's upbringing style is mainly permissive.

One of the key issues with the increased explanatory and prognostic ability is the fatherhood motivation. What place does the parenthood / fatherhood take in the person's value system and among his other social roles? The answers to these questions show that some of the single fathers are characterized by high emotional involvement in the child's life. For them, birth of the child, especially if this is not the first child, was originally desired. Absence of the child mother creates the conditions for maximum self-fulfillment as the parent. In spite of the objections of the surrounding community, such father has not doubts that the child will remain with him. The children are not perceived as a burden despite the difficulties of combining the parental and professional functions. The child for the single father is something "my own" and it is not possible to give this "his own" to someone. However, fatherhood understanding takes place in different ways and depends on early involvement in caring for the child. When the desired children appear, and they are, as a rule, the second and subsequent children, the perception of oneself as a father arises immediately. For men who are highly focused on work and have the desired children, generation of the paternal feeling occurs when emotional involvement into the child upbringing appears and the need to take care of the child subtilizes the fatherhood feeling.

The factors affecting the "involved" fatherhood making depend on the current life situation. In a widowerhood situation, the close relatives of the father become full second parents. In this case, the gender of the relative does not matter in caring for the child. The role of the wife's relatives is often connected with the socio-economic condition of the father's family. In case of the low economic level, the relations are often negative, and in case of the high economic level, the relations are mutual assistance.

For the father, the professional interests and career go into the background as significant time expenditures are required for the child raising and care. Therefore, the father is forced either to resort to assistance of the relatives or to transfer to the part-time work. In case of divorce, a significant part of the father's life that takes away his physical and emotional 
resources (which are necessary for communication with his own child) is the struggle with the judicial system for his paternal rights including determination of the child's place of residence. The relations with his wife's relatives are usually negative, the assistance can only be obtained from his family. In highly profitable and highly professional groups, the father makes a conscious decision to transfer to the part-time work (which, nevertheless, allows him to have an acceptable income level) to have more time for his child. The greatest difficulties are observed in professionally incompetent groups with low income when the work is the main source of income, full-time employment is indispensable, and the relatives can offer only physical assistance. In this case, the child remains without necessary attention of the father and the significant resource in the upbringing begins to belong to the educational institution. At the same time, the living conditions and and financial situation as a whole do not play a decisive role in development of the involved fatherhood. The available financial resources facilitate implementation of care for the physical well-being of the child and development of his abilities; however, the main factor of establishing close paternal-child relations is the motivation- and value-based component of the fatherhood.

Implementation of the paternal practices depends on the influence of the surrounding community as well as the upbringing experience in the parental family and cultural inheritance patterns that each person has. Due to the absence of the child mother, the fathers do not implement the parenting practice used by the mother. The upbringing forms and methods used in the parental family of the father or his own approaches are implemented. In case of divorce, the mother's practices are generally not acceptable for the fathers; they are rejected as wrong and adverse for the child.

The fathers demonstrate different scenarios of intergenerational relations: from full adoption and positive attitude as well as transfer of the parental relations to relations with their own children to complete rejection, rethinking and searching for their own models of interaction with the children. The typical feature for the single fathers participated in the study is early family leaving for various reasons: the beginning of occupational training, early marriages, conflicts with their parents. However, the relations with their own mothers are more definite and positive than with their fathers.

The study revealed the specifics of the intergenerational differences in the life purposes, scenarios, and practices of fatherhood. The intergenerational differences are caused by the socio-historical dynamics between the childhood of the fathers and the childhood of the modern children, technical capabilities of today life, requirements of the educational system.

In general, the fathers can be divided into three groups: the first group is characterized by the positive relations with their fathers and the communication experience transmitted to relations with their children. The second group has negative relations with the fathers due to violence applied to the interviewees in childhood or due to insurmountable mindset differences; in this case, the alternative methods of interaction with their own children are searched. The third group includes the interviewees who lost their fathers at an early age; in this case, they search the fatherhood model by themselves. Regardless of belonging to a particular group, it is important to take into account that the fathers' childhood was during the Soviet period, and the "Soviet" fathers living in the families had primarily to actively work and only then they could take part in the children upbringing. Therefore, all interviewed fathers remember more about female (mother, grandmothers) participation in their upbringing compared to the male one.

\section{Conclusions}

Thus, the poor social and cultural capital of the father results in a shortage of parent-child relations, low level of trust, lack of affection and emotional closeness with the father. However, the fathers who have the expanded cultural capital are active, involved in the 
upbringing of children, and open for communication with them. The different scenarios of intergenerational relations with own fathers and families are described. Thus, the positive relations with the fathers result in adoption of their model of fatherhood, transfer of the parental relations to relations with their own children; the negative relations cause refusal; and the conflicting or missing relations lead to rethinking and searching for own models of interaction with the children. Our paper examined the typical scenarios of a man becoming a single father, social problems, and paternal practices based on the interviews conducted in Saint-Petersburg with 17 single fathers raising minor children.

The results of our study show that single fatherhood is as a rule a forced situation caused by the death or severe illness of the mother, her deviant behavior and leaving the family, deprivation of parental rights, divorce consequences, long-term separation of spouses, use of modern reproductive technologies of surrogacy. Our research testifies to the fact that single fathers tend to become family leaders and undertake responsibility related to childcare in the context of transforming marital and family relations.

The analysis of the interviews has demonstrated that the single fathers experience significant difficulties in arranging their family's life, raising children, communicating with family members, employers, and teachers. This situation is usually typical for the fathers raising children without any help from their relatives. The support of the single fathers raising the children shall be improved within several main areas. It is important to improve the family law by enhancing the legal protection of the fathers and their right to raise children in case of divorce, deviant behavior of the mother or deprivation of her parental rights. According to the fathers, it is necessary to involve the fathers themselves in examination of draft legislation related to support measures for the single parents and paternal families. Many families with the single fathers has a difficult financial situation which requires an expansion of the financial support for such families at the federal, regional, municipal levels (provision of benefits, subsidies, allowances, payments to the single fathers and children). A hot topic is improvement of training of the social work specialists focused on the single-parent families support. It is important to promote the development of charity, civic initiatives aimed at the single-parent (paternal) families support. There is a need for information support, digitalization of social services including consulting on websites, forums, and chat rooms, broadcasting the problems of the single fathers to the media in order to attract public attention to the paternal monoparenthood. Moreover, there is also a need in helping single fathers to become aware of the environmental issues and to convey this knowledge to their children raising their environmental awareness and helping them to get familiar with the sustainable eduction.

\section{Acknowledgment}

The reported study was funded by RFBR, project number 19-011-00543.

\section{References}

1. Goskomstat, https://www.gks.ru/free_doc/new_site/perepis2010/croc/perepis_itogi1612.htm (1989)

2. Federal State Statistics Service of the Russian Federation, https://www.gks.ru/free_doc/new_site/perepis2010/croc/perepis_itogi1612.htm (2010)

3. Federal State Statistics Service of the Russian Federation, https://www.gks.ru/free_doc/new_site/population/demo/micro-perepis/finish/microperepis.html (2015)

4. G.L. Voronin, A.L. Ianak, Woman in Russian Society, 1(86), 53-66 (2018) 
5. O.S. Kirillova, L.E. Petrova, Perm University Herald, 3, 128-136 (2014)

6. N.Y. Egorova, A.L. Yanak, Vestnik of Lobachevsky State University of Nizhni Novgorod, 2(34), 42-46 (2014)

7. I.O. Shevchenko, RSUH/RGGU Bulletin, 4(126), 63-172 (2014)

8. A.I. Mikhailova, Single-Parent (Father) Families: Sociological and Managerial Aspect, Cand. sociol. sciences thesis, Transbaikal State University, 2014

9. A.V. Ermilova, Woman in Russian Society, (78), 69-79 (2016)

10. N.L. Moskvicheva, A.A. Rean, S.N. Kostromina, N.V. Grishina, E.V. Zinovieva, Psychological Science and Education, 24(3), 5-18 (2019)

11. O.N. Bezrukova, Sociological Studies, 11, 118-130 (2013)

12. O.N. Bezrukova, V.A. Samoylova, Sociological Studies, 7, 116-125 (2017)

13. O.V. Kuznetsova, Bulletin of Chelyabinsk State University, 17(372), 89-94 (2015)

14. O.N. Bezrukova, V.A. Samoylova, Sociological Studies, 7, 90-101 (2019)

15. O.V. Stasenko, Woman in Russian Society, 3, 78-82 (2010)

16. Y. Lee, S.L. Hofferth, Journal of Child and Family Studies, 26, 3439-3451 (2017)

17. M. Dufur, N.C. Howell, D.B. Downey, J.W. Ainsworth, A.J. Lapray, Journal of Marriage and Family, 72, 1092-1106 (2010).

18. J.L. Hook, S. Chalasani, Journal of Marriage and Family, 70, 978-990 (2008).

19. S. Demuth, S.L. Brown, Journal of Research in Crime and Delinquency, 41, 58-81 (2004)

20. J. Bronte-Tinkew, M.E. Scott, E. Lilja, Journal of Marriage and Family, 72(5), 11071127 (2010)

21. P. Donati, R. Prandini, International Review of Sociology, 17, 209-223 (2007)

22. R. LaRossa, The Modernization of Fatherhood: A Social and Political History (1997)

23. W.J. Doherty, E.F. Kouneski, Journal of Marriage and Family, 60(2), 277-292 (1998)

24. S. Coltrane, Handbook of Contemporary Families: Considering the Past, Contemplating the Future (2004)

25. I.S. Kon, Man in a changing world (2009)

26. D. Lengersdorf, M. Meuser, Balancing Work and Family in a Changing Society. The Fathers' Perspective (2016)

27. S. Ruby, S. Scholz, Österreich Z Soziol, 43, 73-83 (2018)

28. J.A. Levine, E.W. Pit, New Expectations: Community Strategies for Responsible Fatherhood (1995)

29. A. Mahidin, S. Maulan, Procedia-Social and Behavioral Sciences, 38, 324-333 (2012)

30. K. Malone, Children in the Anthropocene: Rethinking sustainability and child friendliness in cities (2017) 